\title{
Small ruminants as a pathway to reduce urban poverty: An empirical analysis of Sudan
}

\author{
Raga Elzaki ${ }^{1,2}$, Samar Abdalla ${ }^{1,3}$ and Mohammed Al-Mahish ${ }^{1}$
}

1. Department of Agribusiness and Consumer Science, College of Agriculture and Food Science, King Faisal University, Al-Ahsa 31982, Saudi Arabia; 2. Department of Rural Economics and Development, Faculty of Animal Production, University of Gezira, Sudan; 3. Agricultural Research Corporation, Agricultural Economics and Policy Research Centre, Shambat, Sudan.

Corresponding author: Mohammed Al-Mahish, e-mail: malmahish@kfu.edu.sa Co-authors: RE: ragaelzaki@yahoo.co.uk, SA: samar.abdalla77@gmail.com

Received: 04-08-2019, Accepted: 20-11-2019, Published online: 20-12-2019

doi: www.doi.org/10.14202/vetworld.2019.2017-2024 How to cite this article: Elzaki R, Abdalla S, Al-Mahish M (2019) Small ruminants as a pathway to reduce urban poverty: An empirical analysis of Sudan, Veterinary World, 12(12): 2017-2024.

\section{Abstract}

Aim: This study aimed to measure the energetic incidence of poverty and determines the main factors that cause urban poverty. Moreover, the study examines the key role of the livestock sector in poverty reduction in urban regions and develops an analytical tool to aid in urban area poverty mitigation through goats and sheep ownership.

Materials and Methods: The study mainly depends on primary data assembled through structured and unstructured questionnaires, which were distributed among the targeted groups in the urban area in Sudan. Poverty line and poverty indices were calculated and measured using various well-known methods. The causes of poverty were estimated using logistic regression, and the effect of small ruminants in poverty alleviation was estimated using multivariate regression analysis.

Results: The study findings indicate that both food and income poverty lines are less than the standard poverty line. In addition, the results imply that rural migration and crime predictors are among the most important factors in increasing urban poverty in the study area. Furthermore, livestock ownership has a significant impact on poverty reduction.

Conclusion: The study concludes that small ruminants are playing a key role in reducing urban poverty. Thus, the study urges planners and policy-makers to support policies that promote livestock sector development as a strategy to alleviate poverty in Sudan.

Keywords: goats, sheep, urban poverty causes, urban poverty line, urban poverty reduction.

\section{Introduction}

Sudan is an agrarian developing country classified as low income with a per capita income of $<\$ 1,045$ (USD) per year (2019). The Gross Domestic Product at constant prices in 2016 was 41.3 [1]. The last National Household Budget and Poverty Survey in Sudan conducted by the Central Bureau of Statistics (CBS), during 2014/2015 confirmed that $36.1 \%$ of the population in Sudan was living in absolute poverty while urban poverty accounted for $39.9 \%$. The per capita/year is 2966 Sudanese Pound (SDG) in urban areas, which displays higher average consumption levels than rural areas (SDG 2698). Poverty assessment in Sudan has been limited, but studies have provided evidence of high-income poverty. A study conducted by Faki [2] analyzed poverty with wide coverage by state and based on aggregate consumption of five main components (food, non-food, durable goods, housing, and energy). It puts North Sudan

Copyright: Elzaki, et al. Open Access. This article is distributed under the terms of the Creative Commons Attribution 4.0 International License (http://creativecommons.org/licenses/by/4.0/), which permits unrestricted use, distribution, and reproduction in any medium, provided you give appropriate credit to the original author(s) and the source, provide a link to the Creative Commons license, and indicate if changes were made. The Creative Commons Public Domain Dedication waiver (http://creativecommons.org/ publicdomain/zero/1.0/) applies to the data made available in this article, unless otherwise stated. at an overall poverty level of $46.5 \%$. Rural poverty was way above urban poverty $(27 \%)$. An authorized study performed by CBS [1] conducted all over Sudan regions reported that the poor population in urban areas is slightly higher than in rural areas.

Livestock production is a dynamic sector for the National Economy in Sudan. Sudan total domestic livestock population in 2017 was about 104 million heads. Goat populations constituted more than 31 million heads, while sheep population constituted nearly 40 million heads [3]. At the national level, the livestock sector is characterized as the most active sector in national income. The livestock shares are estimated to be $18-25 \%$, and it shares foreign currencies through the export of the various livestock products in the form of live animals, meat, and leathers. In addition, it represents a livelihood activity for about $60 \%$ of the population and provides employment for about $40 \%$ of the population [4]. At household level, livestock is the main source of food, employment, income, transportation, prosperity, and enhancing crop production by providing organic manure fertilizers and draught power. Shrestha et al. [5] indicated that when crops are not sufficient to ensure food security, livestock can be used as a source of food.

Nowadays, in Sudan, no adequate studies have investigated urban poverty reduction, whereas a 
majority of international, national, and regional research has focused on rural poverty reduction [6-9]. The lack of updates to the poverty line and studies of economic policy in urban areas have made it difficult to make comparisons across time, particularly in recent years, through which the country's economy has deteriorated and marginally fallen. Moreover, no recent research has been accomplished toward poverty reduction in Sudan. Likewise, civil wars and political problems led to successive migration from unsecured areas, particularly from rural areas, to urban areas. The unplanned migration created various and serious problems faced by the migrators. Hence, most of the migrators have no access to the basic needs of life and struggle to live in a new environment. Furthermore, the abrupt financial fall of the economy successively led to increased poverty among the rural migrators; those migrators reverse their initial wealth, which are mainly seasonal crops and rearing of livestock.

This study aimed to analyze and measure the poverty indices in the urban areas and to identify the main factors beyond urban poverty causes. Furthermore, the study attempts to construct an identical strategy approach of urban poverty reduction by practicing small ruminants in the indoor household.

\section{Materials and Methods \\ Ethical approval}

For this study, the collection of the questionnaire was approved by the Faculty of Animal Production, University of Gezira, Sudan. The oral permission was obtained from the target's household head in the study area.

\section{Methodology and data description}

Bahri region is selected to act as the study area (located in the Eastern part of Khartoum National Capital). It was selected because the majority of livestock is distributed in this region compared to other regions around Sudan capital. The study mainly depends on primary data assembled through structured and unstructured questionnaires which were distributed among the targeted groups in the urban area in Sudan. About 300 questionnaires were distributed randomly for the household heads in the Bahri region (year 2017/2018). As the study mainly concentrated on extreme poverty (food and non-food expenditures) in the region, the primary data collected to cover the information of monetary (economics data) and nonmonetary indicators (demographic and socioeconomic). The major data include household head ages, jobs, family size, income, foodstuff (types, purchasing prices, consumption, etc.), health, education, housing conditions, water aspects, and its problems, social participation, political conflicts, crimes, and various features of livestock issues.

\section{Poverty line and measurement method}

The poverty line is calculated based on dietary intake kilocalories per equivalent, which is later termed as food poverty, and the situation of household income and expenditures is termed as money or income poverty.

Poverty is a complex and multifaceted problem, and varieties of methodologies are used for poverty calculation and examination. According to objectives and the nature of the data collected, poverty was calculated using the Foster-Greer-Thorbecke (FGT) method suggested by Foster et al. [10]. The investigation follows the cost of basic needs method to poverty analysis, which was performed in many African countries. The three sound methods of poverty measures (headcount ration, poverty gap, and poverty square) were analyzed by succeeding FGT method. In addition, a fourth measure (Watts's index) was calculated. Watts's index takes into account both income and the number of people in poverty [11].

\section{Poverty line}

Assuming that the $Y_{i}$ denotes household income and $Z$ denotes the poverty line, both income and poverty line were calculated by comparing the total expenditure of the individual household by the international poverty line, which was originally set to be roughly $<\$ 2 /$ day [12]. In addition, poverty line was calculated by summation of the kilocalories of Sudanese food staff to the standard kilocalories requirement according to the World Health Organization. The minimum level of Sudanese household's expenditures should enable them to buy $2100 \mathrm{kcal}$ of food per person per day [13]. If the individual consumes less than the required kilocalories (2100), it was considered poor; otherwise, it was nonpoor. Poor $=1$ if $C \leq 2100$ and non-poor $=0$ if $C>2100$, whereas the $C=$ total consumption of kilocalories per day. For estimating the number of poor and non-poor according to their daily expenditure in USD, we assign the value 1 when income $\left(y_{i}\right)$ falls below the poverty line $(z)$ and 0 if income fall above the poverty line. Thus, poor $=1$ if $y_{i} \leq z$ and non-poor $=0$ if $y_{i}>z$.

\section{Poverty indices}

The general FGT equation of poverty indices was measured as below:

$$
P^{\infty}=\frac{1}{n} \sum_{1}^{p_{u}}\left[\frac{z-y}{z}\right]^{\infty}
$$

\section{The headcount}

The headcount was calculated by matching the $Y_{i}$ of each household to $Z$. The headcount index $\left(H_{i}\right)$ was the sample average of the variables weighted by the number of people in each household $n_{i}$. The parameter $\alpha$ determines the measure sensitivity to the degree of deprivation for those below the poverty line [10]. When $\alpha$ equals zero the measure reduces to the below formula:

$$
H i=\frac{p_{u}}{N}
$$

\section{Poverty gap (depth)}

The poverty gap of urban people represents the depth of poverty. It means the distance separating the people from the poverty line. It was generated when 
the parameter $\alpha$ equals $s$ one, which can be defined as follows:

$$
P_{u g}=\frac{1}{n} \sum_{1}^{p_{u}}\left[\frac{z-y}{z}\right]
$$

Whereas $P_{u g}$ is the urban poverty gap.

\section{Poverty square (severity)}

Poverty square or severity reflects the inequality between the poor household. This measure is illustrated by the below equation:

$$
P_{u s}=\frac{1}{n} \sum_{1}^{p_{u}}\left[\frac{z-y}{z}\right]^{2}
$$

\section{Watts' index}

The study tries to calculate Watts' index, which is a function of an individual income and poverty line. It is the first distribution-sensitive poverty measure that was proposed by Watts [11]. Watts' index is calculated by dividing the poverty line by income of the urban sample of the adult equivalent [14]. Taking logs, (which involves the computation of the logarithm of each income) and taking the sum over the poor and the household size variable $n_{i}$ replaced with the adult equivalent size $a^{i}$. According to World Bank [15], the equation of Watts index is represented below:

$\frac{1}{N} \sum_{i=1}^{S}\left[\operatorname{Ln}(z)-\operatorname{Ln}\left(y_{i}\right) I\right]\left(z, y_{i}\right) n_{i}=\frac{1}{N} \sum_{i}^{S} \ln \left(\frac{z}{y i}\right)$

Where $s$ is the total number of the household in the sample.

\section{Logistic method of urban poverty causes}

The study follows various researchers [16-20] to estimate poverty causes using binary logistic regression. Binary regression is used to predict the relationship between dependent variables (predicted variable), which is dichotomous and represents poor versus non-poor households. The independent variables (predictors) represent the demographic features of the sampled population and the types of livestock.

To identify key determinants or causes of poverty, a dichotomous variable indicating whether the household is poor or not is computed [19]. Estimated probability of being poor, given the values of explanatory variables, in this study is a single categorical variable:

$$
\pi=p_{r(P=1 \mid X=x)}
$$

$\pi=$ is predicted probability, $P_{r}=$ probability, and $P$ is a binary variable of poor household. $P_{i}=1$ if the household is poor in observation $i$, otherwise $P_{i}=0$, if the household is not poor in observation $i$.

The $X_{s}$ values are a set of predictors, which can be discrete, for instance, number of animals, family size, etc., also, it can be continuous, such as age and income.

Later the poverty binary model could be:

$$
\pi=P_{r}\left(P_{i}=1 \mid X_{i}=x_{i}\right)=\frac{\exp \left(\beta_{0+} \beta_{1}\right)}{1+\exp \left(\beta_{0+} \beta_{1 x_{i}}\right)}
$$

$$
\begin{aligned}
& \operatorname{Logit}\left(\pi_{i}\right)=\log \left(\frac{\pi_{i}}{1-\pi_{i}}\right) \\
& P_{r}=\beta_{0+} \beta_{\mathrm{i}} x_{i}+\varepsilon
\end{aligned}
$$

$\beta_{0}=$ a cluster fixed or random effect and $\beta$ is a vector of parameters.

$x_{i}$ is a vector of household demographic features or others explanatory variables, which include a set of individual characteristics $X$ (e.g., gender, education, age of the household head, and livestock ownership). Furthermore, some political variables are included in the model, for example, rural migration due to crimes and/or conflicts.

\section{Poverty reduction model}

One of the key issues of various international institutions [21,22] is to suggest and adopt the various types of policies and strategies for poverty reduction in the world in general and poverty reduction in developing countries in Africa, specifically. Hence, widespread malnutrition and most African nations are agrarian and depend mainly on crop production as the main source of income generation. The strategy used for urban poverty reduction in this study is through livestock practicing. The study selected two livestock, which is goats and sheep. Thus, these two types of livestock are much cheaper and simply can be kept inside homes.

\section{Poverty line elasticity model}

Numerous researchers investigate poverty reduction, taking into account the different forms and formula of poverty elasticity with respect to growth, income, inequality, and standard of living [10,23-26]. Our study tries to analyze the poverty lines' (income and food poverty) elasticities to display the responsiveness, or how poverty lines change in response to a livestock production change.

To explain the role of livestock in poverty eradication in urban areas, the study uses a regression model to evaluate the incorporation of the livestock in the household to reveal the importance of practicing livestock activities in the household. Multiple regression procedures are constructed to explain the relative response of per capita income to increases in goats and sheep heads, and hence the poverty alleviation. The equation can be written as follows:

$$
Y_{p}=\beta_{0}+\beta_{2}(\text { Goat })+\beta_{2}(\text { Sheep })+\varepsilon
$$

Equation (11) is a log-linear model aiming to estimate the poverty elasticity with respect to numbers of sheep and goats owned by the household as follows:

$$
\ln Y_{p}=\ln \beta_{0}+\ln \beta_{1}(\text { Goat })+\ln \beta_{2}(\text { Goat })+\varepsilon
$$

Where $Y_{p}=$ poor income and the predictor variables are goat and sheep heads, respectively. Extra equations of the multiple regressions are performed to show the effect of livestock production in food poverty reduction. In this equation, the dependent variable used is food poverty line and the independent's 
variables used are consumption of both milk and meat in the households, as shown by Equation (12).

$$
Z=\beta_{0}+\beta_{2} M_{c} M C+\beta_{2} M t_{c}+\varepsilon
$$

Equation (13) is a log-linear model to estimate poverty elasticity with respect to milk and meat consumption by the household as follows:

$$
\ln Z=\ln \beta_{0}+\ln \beta_{2} M_{c} M C+\ln \beta_{2} M T C+\varepsilon
$$

Whereas $Z=$ food poverty line, $M C=$ milk consumption, and $M T C=$ meat consumption. The regression models were executed using the capabilities of SPSS, SAS, and Excel software programs.

\section{Results}

The descriptive results show that $65 \%$ of respondents are males while $35 \%$ are females. The majority of females migrated from civil wars or conflict areas in Western or Eastern regions or escaped from natural hazards in Northern regions.

The average age of the surveyed household headed is 52 years. The average family size is found to be approximately eight people, and this is a normal phenomenon in Sudan.

Considerable numbers of the surveyed samples $(35 \%)$ are unschooled and almost illiterate, and practicing the informal jobs ranged between street sellers to hired labors with marginal employers. Only 4.3\% received university education and those were the only segment of the sampled survey who own houses. According to the food poverty line (household member that consumed $(<2100 \mathrm{kcal})$, the numbers of the poor constituted nearly $222(74 \%)$ while the non-poor are 78 (26\%). Most of the poor households are females $(85 \%)$ and the remainder are males $(15 \%)$.

\section{Urban food consumption and poverty line}

From Table-1 [27], it is clear that household actual consumption is $1888.09 \mathrm{cal}$, which is less than the recommended calories by $9.6 \%$. It is notable that coffee comprises a higher food poverty line (SDG 107.96) followed by cereal food (SDG 62.35). In addition, the study result confirms that the food poverty line is 8.48 /household and equal to $\$ 1.04 /$ person (average family size eight people). The non-food expenditure is estimated to be 132.5 SDG. Furthermore, the extreme poverty line is estimated to equal nearly $11.80 \mathrm{SDG} /$ household and $\$ 1.47$ person (Tables-1 and 2).

As shown in Table-2, the urban poverty measurements reveal that the proportion of those who live below the poverty line is $74 \%$, which indicates that more than half the surveyed sample is poor. Likewise, the poverty depth and severity are estimated to be $68.28 \%$ and $45.26 \%$, respectively. Furthermore, it implies that $68.28 \%$ of the poor are slightly far from the poverty line (1.04). In addition, the mean proportionate poverty gap of the urban poor is high, as shown by Watts' index (55.25\%).

\section{Urban poverty causes}

The connection between risk factors and the incidence of urban poverty is shown in Table- 3 .

The goodness of fit of the model is shown to be significant $\left(\chi^{2}=39.58\right)$. The logistic regression result shows

$\overline{1 \text { One USD }}=32.50 \mathrm{SDG}$ at the time of survey.

\begin{tabular}{|c|c|c|c|c|c|}
\hline Food elements & ACC/day & RC/day* & $\mathbf{N C} / \mathbf{k g} *$ & $\mathbf{P} / \mathbf{k g}$ in SDG & Poverty line in SDG \\
\hline \multicolumn{6}{|c|}{ Cereal food consumption } \\
\hline Sorghum & 1178.23 & 884.1454 & 0.263924 & 165.451 & 43.66 \\
\hline Wheat & 52.15 & 199.4372 & 0.054941 & 170.909 & 9.39 \\
\hline Millet & 5.58 & 194.3744 & 0.058022 & 160.383 & 9.3 \\
\hline Subtotal & 1235.96 & 1277.957 & 0.376887 & 496.743 & 62.35 \\
\hline \multicolumn{6}{|c|}{ Animal products food consumption } \\
\hline Meat & 99.23 & 98.88078 & 0.048951 & 250.278 & 12.25 \\
\hline Milk & 32.78 & 74.15888 & 0.115873 & 137.982 & 15.98 \\
\hline Chicken & 23.5 & 418.9922 & 0.046555 & 412.480 & 19.2 \\
\hline Egg & 39.011 & 6.20615 & 0.004433 & 438.950 & 1.95 \\
\hline Subtotal & 194.521 & 598.238 & 0.215812 & 1239.69 & 49.38 \\
\hline \multicolumn{6}{|l|}{ Vegetables } \\
\hline Okra & 7.5 & 8.946715 & 0.008284 & 1950.506 & 16.15 \\
\hline Onion & 12.5 & 7.52132 & 0.015669 & 90.200 & 1.41 \\
\hline Tomatoes & 25.23 & 29.82238 & 0.06213 & 180.653 & 11.22 \\
\hline Other vegetables & 27.21 & 48.00952 & 0.032006 & 780.235 & 24.97 \\
\hline Subtotal & 72.44 & 94.29994 & 0.118089 & 3001.594 & 53.75 \\
\hline \multicolumn{6}{|l|}{ Coffee } \\
\hline Sugar & 177.269 & 295.7592 & 0.07394 & 150.28 & 11.11 \\
\hline Tea & 3.5 & 11.55864 & 0.010702 & 9050.102 & 96.85 \\
\hline Subtotal & 180.769 & 307.3178 & 0.084642 & 9200.382 & 107.96 \\
\hline \multicolumn{6}{|l|}{ Others needs } \\
\hline Salt & 4.15 & 3.018763 & 0.013722 & 850.460 & 11.67 \\
\hline Oil & 200.25 & 8.583058 & 0.012089 & 192.180 & 2.32 \\
\hline Subtotal & 204.4 & 11.60182 & 0.025811 & 1042.64 & 13.99 \\
\hline Overall total & 1888.09 & 2289.414606 & 0.821241 & 5852.049 & 287.43 \\
\hline
\end{tabular}

Table-1: Food consumption of households in Bahri region.

Source: Field surveyed results, 2017/2018. *Data from the World Health Organization [27]. ACC=Actual consumed kilocalories, $\mathrm{RC}=$ Required kilocalories, NC=Numbers of kilocalories in food items, $\mathrm{P}=$ Price of food items 
Table-2: Urban poverty measurements in Bahri region.

\begin{tabular}{lclc}
\hline Income poverty line & Value & Poor and poverty measures & Value \\
\hline Average of food expenditures & 5852.049 SDG & Number of the total samples & 300 \\
Average of non-food expenditures & 132.5 SDG & Number of poor & 222 \\
Total expenditure & 5984.549 SDG & Headcount index & $74 \%$ \\
Average of family size & Eight persons & Poverty gap (depth) & $68.28 \%$ \\
Poverty line & $1.04 \$$ & Poverty square (severity) & $45.26 \%$ \\
Extreme poverty line & $1.47 \$$ & Watts index & $55.25 \%$ \\
\hline
\end{tabular}

Source: Field surveyed results, 2017/2018

Table-3: Model of risk factors causing urban poverty.

\begin{tabular}{|c|c|c|c|c|c|c|}
\hline \multirow[t]{2}{*}{$\begin{array}{l}\text { Predictors/explanatory } \\
\text { variables }\end{array}$} & \multirow[t]{2}{*}{$\begin{array}{c}\text { Estimated coefficient } \\
(\beta)\end{array}$} & \multirow[t]{2}{*}{ Standard error } & \multirow[t]{2}{*}{ Wald } & \multirow[t]{2}{*}{$\begin{array}{l}\text { Odds ratio exp } \\
(\beta)\end{array}$} & \multicolumn{2}{|c|}{$\begin{array}{l}\text { 95\% of C.I. for } \\
\text { odds ration }\end{array}$} \\
\hline & & & & & Lower & Upper \\
\hline Gender & -0.768 & 0.525 & 0.856 & 0.626 & 0.325 & 1.700 \\
\hline MHHA & -0.008 & 0.051 & 0.120 & 0.995 & 0.852 & 1.053 \\
\hline EDL & -0.358 & 0.133 & 2.566 & 0.460 & 0.453 & 1.009 \\
\hline $\mathrm{OL}$ & -0.452 & 0.199 & 3.926 & 0.730 & 0.505 & 1.078 \\
\hline FIJ & 0.003 & 0.078 & 0.000 & 1.002 & 0.728 & 2.302 \\
\hline FS & 0.778 & 0.235 & 0.812 & 1.512 & 0.122 & 1.598 \\
\hline NM & 0.815 & 0.485 & 1.054 & 2.052 & 0.429 & 8.582 \\
\hline NF & 0.528 & 0.480 & 1.125 & 2.058 & 0.752 & 6.458 \\
\hline CA & 1.221 & 0.245 & 11.458 & 3.316 & 0.155 & 0.482 \\
\hline DA & 0.296 & 0.456 & 0.350 & 1.344 & 0.250 & 5.122 \\
\hline $\mathrm{CW}$ & -0.128 & 0.223 & 0.268 & 0.211 & 0.284 & 2.596 \\
\hline $\mathrm{HC}$ & -0.259 & 0.487 & 0.278 & 1.457 & 0294 & 3.256 \\
\hline RMIG & 0.810 & 0.235 & 9.125 & 4.125 & 0.258 & 6.289 \\
\hline Constant & 3.889 & 1.449 & 6.758 & 52.033 & \multicolumn{2}{|c|}{$\chi^{2}=39.58$} \\
\hline
\end{tabular}

*Note: $\mathrm{MAHH}=$ Male household headed age, $\mathrm{EDL}=$ Education level, $\mathrm{OL}=\mathrm{Own}$ livestock, FIJ=Types of jobs, FS=Family size, $\mathrm{NM}=$ Numbers of males, $\mathrm{NF}=$ Number of females, $\mathrm{CA}=$ Crimes attach, $\mathrm{DA}=$ Diseases affections, $\mathrm{CW}=\mathrm{Clean}$ water, $\mathrm{HC}=$ Health care, and RMIG=Migration. Binary logistic statistics: $*$ Number of observations $=300$, Adjusted R-squared: 0.400, 2-Log likelihood=250.613. Source: Field surveyed results, 2017/2018

that there is an increase in the likelihood of being poor with job types, family size, number of males, crimes, diseases, affection, and migration (the odd ratios $>1$ ). Male household head age, education level, and livestock ownership have odds ratios $<1$, which indicate that the likelihood of being poor is decreased for these variables. Education level has a low value of odds ratio (0.460); this indicates that the poor living in urban regions have more access to education. Moreover, the findings show that households with access to clean water were significantly less likely to be in poverty compared to households without access to clean water. However, residents living in extreme poverty suffer from the risks of other factors, such as no access to health care and disease infections (including malnutrition).

Migration and crime predictors were among the most important factors in increasing urban poverty in this study.

\section{Role of small ruminants in urban poverty reduction}

Ram [26], using the panel data of Vietnam, suggested that livestock production contributes to poverty reduction. The multiple regression models were run to estimate the impact of livestock on poverty reduction (Tables-4 and 5). The overall model is significant $\left(\mathrm{F}=59.64, \mathrm{R}^{2}=0.570\right)$.

Based on the multiple regression model results, the study shows that the increase in goat numbers lead to increase in the per capita income of the urban poor by 33.79 SDG. In addition, when the sheep numbers increase by one head, the per capita income increases by $41.57 \mathrm{SDG}(\mathrm{t}=5.613)$. Furthermore, a $1 \%$ increase in goat and sheep heads increases per capita income by $0.54 \%$ and $0.30 \%$, respectively.

On the other hand, the results in Table-5 show a direct connection between poverty reduction and consumption of livestock products (meat). If meat consumption increases by $1 \mathrm{~kg}$, the kilocalories of the household increase by $126 \mathrm{kcal}$. However, milk consumption had an insignificant effect on households' kilocalories.

Based on the elasticities estimation, all results were inelastic, as shown in Tables-4 and 5. Table-5 shows that a $1 \%$ increase in meat consumption results in a $0.957 \%$ increase in the urban poor kilocalories.

\section{Discussion}

Urban poverty becomes core attention of the developing countries' governments within which the people suffer from refugees, civil wars, and resource conflict. Adequately, studies are performed worldwide using different methods of urban poverty measurements and roughly compare rural poverty to urban poverty.

In this study, the results show that there is an increase in the likelihood of being poor with family 
Table-4: Influence of small ruminants on per capita income of the urban poor.

\begin{tabular}{lccccc}
\hline Model & Value of coefficient & t-value & Significance & F-value & $\mathbf{R}^{\mathbf{2}}$ \\
\hline Constant & -1179.04 & -1.459 & 0.148 & $59.64(0.000)$ & 0.570 \\
Goats & 33.793 & 3.162 & 0.002 & & \\
Sheep & 41.575 & 5.613 & 0.000 & & \\
\hline \multicolumn{7}{c}{ Poor income elasticity } \\
\hline Elasticity & DF & Parameter estimate & Standard error & t value & Pr $>$ |t $\mid$ \\
\hline Goats & 1 & 0.54095 & 0.03305 & 16.37 & $<0.0001$ \\
Sheep & 1 & 0.30192 & 0.03666 & 8.24 & $<0.0001$ \\
\hline
\end{tabular}

Source: Fled surveyed results, 2017/2018

Table-5: Influence of small ruminants on the total kilocalories consumption.

\begin{tabular}{lccccc}
\hline Model & Value of coefficient & t-value & Significance & F-value & $\mathbf{R}^{\mathbf{2}}$ \\
\hline Constant & 2265.090 & 2.975 & 0.003 & $16.78(0.000)$ & 0.190 \\
Milk consumption & 5.100 & 0.800 & 0.425 & & \\
Meat consumption & 125.916 & 3.140 & 0.002 & & \\
\hline \multicolumn{7}{c}{ Total kilocalories consumption elasticity } & & \\
\hline Elasticity & \multicolumn{2}{c}{ Parameter estimate } & Standard error & t-value & Pr $>$ |t | \\
\hline Milk consumption & 1 & 0.12644 & 0.08907 & 1.42 & 0.1568 \\
Meat consumption & 1 & 0.95737 & 0.08391 & 11.41 & $<0.0001$ \\
\hline
\end{tabular}

Source: Filed surveyed results, 2017/2018

size (Table-3) and this result confirmed by Kabir and Maitrot [28] who stated that the larger the size of the beneficiary's household, the more negative the effect on economic growth and well-being. Furthermore, this study reveals that migration is constantly contributing to increase poverty incidence in the urban area; however, Christiaensen [29] showed that in Tanzania, the migration to secondary towns helps in poverty reduction.

In addition, De Janvry and Sadoulet [30] analyzed the change in the relative number of rural and urban poor using aggregate analysis. Their findings showed that the incidence of rural poverty was declining relative to the incidence of urban poverty, and the population was rapidly leaving in the rural sector. In addition to the universal increase in commodity prices, food prices steered to increase urban poverty incidences. The study results indicate that food price is high, which is influenced by urban poverty and this result agrees with the findings argued by Meng et al. [31] that the poverty line is linked positively with an increase in relative food price. Study shows a deep level of deprivation and higher incidence of poverty for urban people who are under the poverty line in the study area, while De Janvry and Sadoulet [30] found that urban poverty dominates aggregate poverty; the urban poor captures more than half of the aggregate increase in real income. Furthermore, De Janvry and Sadoulet [30] indicated that the incidence of rural poverty in Latin American countries is considerably higher and deeper than the incidence of urban poverty. The study result displays that the poverty income is sensitive in the urban area; however, De Janvry and Sadoulet [30] stated that the overall rural poverty is less sensitive to aggregate income growth compared to urban poverty and Yamada [32] used the quantile regression model and argued that the coefficients in urban areas are larger than rural area. Moreover, the regression coefficients have been decreasing slightly as time passes and do not have constant changes across the deciles. Employment tends to affect food poverty dynamics differently in urban and rural areas. The results of logistic regression used in this study reveal that there is an increase in the likelihood of being poor with job types. Eigbiremolen and Ogbuabor [33] used the dynamic food poverty continuous model in Nigeria to examine the impact of selected covariates on $(\log )$ growth of food consumption expenditure and the outcome showed that urban households which have a household head that is employed, increases his/her per capita spending on food over time in relation to households whose heads are unemployed. Thus, the authors conclude that employment reduces food poverty. Cho [34] indicated that households in urban areas were found to be multi-dimensionally poor. Some researchers went beyond child labor poverty in urban areas, such as Dayioğlu [35], who investigated the determinants of child labor in urban Turkey with low household income or in poverty using a probit model. The results showed that child employment goes down with household income. However, the effect of household income on child employment is not great, and the likelihood of children's employment is highly significant.

Poverty reduction has been a political priority from most developing nations and received great attention to international organization agendas $[26,36]$. The strategy used for urban poverty reduction in this study is through livestock practicing. Accordingly, different strategies and policies of poverty reduction are executed worldwide. Alwang et al. [37] examined 
the poverty reduction through innovations to improve staple crop germplasm and found that the main difficulties to greater poverty reduction include limited access to credit, services and markets, and small landholding sizes of poor farmers. Furthermore, the authors confirm that landholding size is an important barrier to poverty reduction. In addition, farm's technologies that enhance farm productivity can be a sustainable pathway to improve household food security and to enable households to climb out of poverty [38]. However, van Noordwijk [39] examined integrated natural resources management as a pathway to poverty reduction, while Benfica et al. [40] argued that providing extension services to smallholders is most effective at raising growth and reducing poverty. An increase in the output would increase farmers' income and reduce poverty in rural areas [41].

The farmers adopting more adaptation practices have higher food security and a lower level of poverty [42]. Martin [43] argued that the focus should be on the sustainability of local socio-technical systems, even if the options chosen are less efficient in the short term. Hansen [44] argued that climate-risk management interventions could play in efforts to reduce rural poverty. There are no studies and/or reviews that empirically analyze the relationship between poverty reduction and women's human rights [45].

The study results confirmed that urban poverty could be alleviated and reduced by the consumption of livestock products (Table-5). By viewing the alleviation and reduction of poverty through practicing livestock, remarkable investigations have performed in this matter. Do et al. [46] evaluated the impact of livestock production on poverty reduction and estimated the average treatment effect on the treated using the matching-difference-in-difference method. They indicated that owning a large livestock size meaningfully reduces the depth of poverty, and access to dairy livestock assets can provide important benefits for women [36]. However, Ali [47] argued that despite climate risk, decreased livestock production increased household income and lowered poverty levels.

\section{Conclusion}

Most developing countries face both rural and urban poverty during recent years. Based on the case study in urban Sudan, this article measures the incidence of poverty and determines the main factors that cause urban poverty. Furthermore, the study examines the vital share of the livestock sector in urban poverty reduction and develops an analytical tool helping to mitigate poverty in urban areas through goats and sheep ownership. The study adopted the standard tool of poverty measurements and estimated the urban poverty line and poverty indices (headcount, depth, severity, and Watts index). Furthermore, the study used logistic regression to reveal the likelihood of poverty determinants. Multiple regression models were also used to show the role of livestock in poverty reduction. In addition, livestock elasticities were estimated to display the responsiveness of poverty lines to changes in livestock production.

The model incorporated small ruminants as a strategy for poverty alleviation. The results indicate that both food and income poverty lines are less than the standard poverty line. In addition, the results implied that rural migration and crimes are among the most important factors contributing to the increase in urban poverty in the study area. The study concluded that small ruminants are playing a key role in urban poverty reduction. The study suggests that planners and policy-makers should encourage policies that promote livestock development and increase financial credit of livestock production. The purpose is to escalate the urban poor beyond poverty and helps them to obtain the basic needs of life, especially for the migrators who escaped from vulnerable regions.

\section{Authors' Contributions}

RE suggested and scheduled the study, managed the data collection, analyzed and manipulated the statistical analysis, and interpreted the results, and approved the final draft of the manuscript. MA contributed to data analysis and interpretation, modified, and revised the final draft of the manuscript. SA wrote the literature review and approved the final draft.

\section{Acknowledgments}

The authors especially appreciate the Faculty of Animal Production, University of Gezira, Sudan, for helping in data collection. Further, the authors would like to extend their sincere esteems to the Central Bureau of Statistics, Sudan, for providing supportive secondary information. The authors did not receive any fund for this study.

\section{Competing Interests}

The authors declare that they have no competing interests.

\section{Publisher's Note}

Veterinary World remains neutral with regard to jurisdictional claims in published institutional affiliation.

\section{References}

1. Central Bureau of Statistics. (2019) Central Bureau of Statistics, Sudan National Household Budget and Poverty Survey 2014/15. Central Bureau of Statistics, Khartoum, Sudan.

2. Faki, H. (2012) Poverty Assessment Northern Sudan (Poverty Assessment and Mapping in Sudan Part 1), Khartoum, Sudan.

3. Food and Agriculture Organization Corporate Statistical Database. (2019) Food Organization of the United Nations, Statistical Data, Live Animal. Food and Agriculture Organization Corporate Statistical Database, Rome, Italy.

4. Ministry ofEnvironment, Forestry andPhysicalDevelopment. (2014) Sudan $5^{\text {th }}$ National Report to The Convention on Biological Diversity. Ministry of Environment, Forestry and Physical Development, Khartoum, Sudan.

5. Shrestha, H., Bhandari, T., Karky, B. and Kotru, R. (2017) 
Linking soil properties to climate change mitigation and food security in Nepal. Environments, 4(2): 29.

6. World Bank. (2011) A Poverty Profile for the Northern States of Sudan. World Bank, Washington, DC. Available from: http://www.worldbank.org. Last accessed on 12-12-2019.

7. Guedes, G.R., Brondízio, E.S., Barbieri, A.F., Anne, R., Penna-Firme, R. and D'Antona, Á.O. (2012) Poverty and inequality in the Rural Brazilian Amazon: A multidimensional approach. Hum. Ecol. Interdiscip. J., 40(1): 41-57.

8. De Sherbinin, A., VanWey, L.K., McSweeney, K., Aggarwal, R., Barbieri, A., Henry, S. and Walker, R. (2008) Rural household demographics, livelihoods and the environment. Glob. Environ. Change, 18(1): 38-53.

9. Perret, S., Anseeuw, W. and Mathebula, N. (2005) Poverty and livelihoods in Rural South Africa. Investigating diversity and dynamics of livelihoods. Case studies in Limpopo. Unpublished Project Report No. 05/01. Kellogg's Foundation, University of Pretoria, Michigan. p65.

10. Foster, J., Greer, J. and Thorbecke, E. (1984) A class of decomposable poverty measures. Econometrical, 52(3): 761-766.

11. Watts, H.W. (1969) An Economic Definition of Poverty, No. 1907-2017-1986.

12. World Bank. (2018) Annual Report. World Bank, Northwest Washington, DC, USA. http://www.worldbank.org/en/ topic/poverty. Last accessed on 12-12-2019.

13. Central Bureau of Statistics. (2014) Central Bureau of Statistics, Sudan National Household Budget and Poverty Survey 2014/15. Central Bureau of Statistics, Khartoum, Sudan.

14. Zheng, B. (1993) An axiomatic characterization of the Watts poverty index. J. Econ. Lett., 42(1): 81-86.

15. World Bank. (2005) Introduction to Poverty Analysis. World Bank, Northwest Washington, DC, USA.

16. Coudouel, A., Hentschel, J.S. and Wodon, Q.T. (2002) Poverty measurement and analysis. In: A Sourcebook for Poverty Reduction Strategies. Vol. 1. World Bank, Washington, DC. p27-74.

17. Mok, T.Y., Gan, C. and Sanyal, A. (2007) The determinants of urban household poverty in Malaysia. J. Soc Sci., 3(4): 190-196.

18. Hashmi, A.A., Sial, M.H. and Hashmi, M.H. (2008) Trends and determinants of rural poverty: A logistic regression analysis of selected districts of Punjab. J. Pak. Dev. Rev., 47(4): 909-923.

19. Achia, T.N., Wangombe, A. and Khadioli, N. (2010) A logistic regression model to identify key determinants of poverty using demographic and health survey data. Eur. J. Soc. Sci., 13(1): 38-45.

20. Sekhampu, T.J. (2013) Determinants of poverty in a South African township. J. Soci. Sci., 34(2): 145-153.

21. World Bank. (2019) The Poverty Reduction Strategy Initiative an Independent Evaluation of the World Bank's Support Through 2003. World Bank, Washington, DC.

22. Food and Agriculture Organization. (2019) Reduce Rural Poverty. Food and Agriculture Organization, Rome, Italy.

23. Heltberg, R. (2002) The Poverty Elasticity of Growth, No. 2002/21. WIDER Discussion Papers//World Institute for Development Economics (UNU-WIDER).

24. Foster, J. (1998) Absolute versus Relative Poverty. Am. Econ. Rev., 88(2): 335-341.

25. Ravallion, M., Datt, G. and Van De Walle, D. (1991) Quantifying absolute poverty in the developing world. Rev. Income Wealth, 37(4): 345-361.

26. Ram, R. (2013) Income elasticity of poverty in developing countries: Updated estimates from new data. Appl. Econ. Lett., 20(6): 554-558.

27. World Health Organization. (2017) World Health Organization, Sudan Office. Food Staff Kilocalories for Sudanese, Khartoum, Sudan. World Health Organization, Geneva.

28. Kabir, A. and Maitrot, M.R.L. (2019) Qualitative exploration of factors affecting progress in antipoverty interventions: Experiences from a poverty-reduction program in Bangladesh. J. Cogent Soc. Sci., 5(1): 1602986.

29. Christiaensen, L., De Weerdt, J. and Kanbur, R. (2019) Decomposing the contribution of migration to poverty reduction: Methodology and application to Tanzania. Appl. Econ. Lett., 26(12): 978-982.

30. De Janvry, A. and Sadoulet, E. (2000) Rural poverty in Latin America: Determinants and exit paths. J. Food Policy, 25(4): 389-409.

31. Meng, X., Gregory, R. and Wang, Y. (2005) Poverty, inequality, and growth in urban China, 1986-2000. J. Comp. Econ., 33(4): 710-729.

32. Yamada, T. (2018) Dynamics of spatial inequality and poverty: Evidence from two decades of surveys in Vietnam, 1993-2014. Econ. Bull., 38(1): 404-418.

33. Eigbiremolen, G.O. and Ogbuabor, J.E. (2018) Measurement and determinants of food poverty: A dynamic analysis of Nigeria's first panel survey data. J. Afr. Dev. Rev., 30(4): 423-433.

34. Cho, S.H., Jung, S., Roberts, R.K. and Kim, S.G. (2012) Interrelationship between poverty and the wildland urban interface in metropolitan areas of the Southern US. J. Appl. Econ., 44(11): 1405-1416.

35. Dayioğlu, M. (2006) The impact of household income on child labor in urban Turkey. J. Dev. Stud., 42(6): 939-956.

36. Bain, C., Ransom, E. and Halimatusa'diyah, I. (2018) "Weak winners" of women's empowerment: The gendered effects of dairy livestock assets on time poverty in Uganda. J. Rural Stud., 61, 100-109.

37. Alwang, J., Gotor, E., Thiele, G., Hareau, G., Jaleta, M. and Chamberlin, J. (2017) Pathways from research on improved staple crop germplasm to poverty reduction for smallholder farmers. Agric. Syst., 172: 16-27.

38. Emmanuel, W.A., Liebenehm, S. and Waibel, H. (2019) The impact of integrated livestock disease management for food security in Togo. Int. J. Agric. Sustain., 17(1): 1-17.

39. van Noordwijk, M. (2017) Integrated natural resource management as a pathway to poverty reduction: Innovating practices, institutions and policies. Agric Syst., 172(1): 60-71.

40. Benfica, R., Cunguara, B. and Thurlow, J. (2019) Linking agricultural investments to growth and poverty: An economywide approach applied to Mozambique. Agric. Syst., 172(C): 91-100.

41. Pratama, M.F., Rauf, R.A., Antara, M. and Basir-Cyio, M. (2019) Factors influencing the efficiency of cocoa farms: A study to increase income in rural Indonesia. PLoS One, 14(4): 1-15.

42. Ali, A. and Erenstein, O. (2017) Assessing farmer use of climate change adaptation practices and impacts on food security and poverty in Pakistan. Climate Risk Manag., 162(2017): 183-194.

43. Martin, D.P. (2019) Knowledge transfer models and poverty alleviation in developing countries: Critical approaches and foresight. Third World Q., 40(7): 1-22.

44. Hansen, J., Hellin, J., Rosenstock, T., Fisher, E., Cairns, J., Stirling, C. and Campbell, B. (2019) Climate risk management and rural poverty reduction. Agric. Syst., 172(June): 28-46.

45. Meinzen-Dick, R., Quisumbing, A., Doss, C. and Theis, S. (2019) Women's land rights as a pathway to poverty reduction: Framework and review of available evidence. Agric. Syst., 172(June)72-82.

46. Do, T.L., Nguyen, T.T. and Grote, U. (2019) Livestock production, rural poverty, and perceived shocks: Evidence from panel data for Vietnam. J. Dev. Stud., 55(1): 99-119.

47. Ali, A. (2018) Impact of climate-change risk-coping strategies on livestock productivity and household welfare: Empirical evidence from Pakistan. J. Heliyon, 4(10): 1-22. 